\title{
NOVÁ STŘíBRNÁ KAPTORGA ZE STŘEDNÍCH ČECH V SOUVISLOSTI S KONKRÉTNIIM VÝROBNÍM OKRUHEM(?) V PRAZE ${ }^{1}$
}

\author{
NEW SILVER KAPTORGA FROM MIDDLE BOHEMIA IN RESPONSE \\ TO AN IDENTIFIED PRODUCTION CENTRE IN PRAGUE(?)
}

\begin{abstract}
In response to the new find of a small silver trapezoid casket - i.e. kaptorga - from the grave of female H 2103 from Hostivice-Palouky, we focused our paper on the small group of such amulet caskets from Central Bohemia, decorated with engraved animal motifs on a punched background and with a knot made with the assistance of a pair of compasses on their lids and dated to the $2^{\text {nd }}$ half of the $10^{\text {th }}$ century. The kaptorga from Hostivice belongs to the Bohemian openable construction type IA, and was decorated with an engraving of a pair of birds with their heads turned on eitherr side of a stylized tree of life with leaf-shaped tendrils. Most of the finds from Hostivice, Klecany II, Praha-Lumbe Garden were produced in Prague during the $2^{\text {nd }}$ half of the $10^{\text {th }}$ century.
\end{abstract}

Keywords: Early Medieval, Bohemia, burial grounds, female graves, metal kaptorga, protective amulet.

\section{1. ÚVOD}

V tomto př́spěvku se budeme zabývat několika raně středověkými hroby s nálezy kaptorg ve středních Čechách v souvislosti s novým nálezem z hrobu H 2103 v Hostivici-Paloukách, okr. Praha-západ, učiněným v roce 2011 pod vedením D. Daněčka.

Kaptorgy jsou jednoznačně schránky na magické substance, zajištující ochranu své nositelce, tedy pouze ženský amulet. Jejich funkční obdobou jsou v západní

\footnotetext{
* CSc Archeologický ústav Praha AV ČR, v.v.i., Letenská 4, 11801 Praha 1, v.v.i. Česká republika, profantova@arup.cas.cz. post.cz.

"Středočeské muzeum v Roztokách, Zámek 1, Roztoky u Prahy, Česká republika, d.danecek@ r. 1993.

Práce je věnována prof. Hanně Kóćka-Krenz, která vytvořila soupis polských kaptorg vydaný
} 
Evropě zavírací okrouhlé schránky na amulety z merovejských hrobů 6.-7. století, objevující se vzácně i karpatské kotlině (Vida 1995).

V roce 2010 jsme shrnuly problematiku typologie a výroby kaptorg v Čechách - oblasti, odkud známe ve střední Evropě nejstarší hrobové nálezy, bezpečně zařaditelné již do poloviny a 2. poloviny 9. století (Profantová i Šilhová 2010). Naše poznatky mají pak význam i pro zkoumání kaptorg na území severně od Krkonoš/ Sudet, tedy v Polsku a Německu, odkud jen menší procento nálezů pochází z hrobů (cf. Kóćka-Krenz 1993; Sztyber 2006, Tab. 1, map. 1-3, Sztyber 2010, s. 43-45). Na tomto území je také jiný poměr zastoupení různých typů kaptorg a více neúplných kusů.

Přinesly jsme poměrně nové informace o jejich magickém obsahu na základě studia pomocí infračervené spektroskopie v kombinaci s mikroskopickým snímkováním (Profantová i Šilhová 2010, tab. 1, Profantová 2015, obr. 7. 36, 12.13, Profantová a kol. 2010, fototab. 64, 91, 92). Kaptorgy v Čechách nejčastěji obsahovaly lněná vlákna, vzácněji i kůstky či chlupy nebo vlasy, textil, vosk.

Podkladem pro detailní studium výroby lichoběžníkovitých kaptorg s víčkem se stala kaptorga z hrobu 22 v Klecanech (obr. 3:1, objevená roku 2000), z výlučné elitní nekropole z 10. století označované jako pohřebiště II (Profantová 2011). Obě kaptorgy patří do stejného výrobního okruhu, který se $\mathrm{v}$ rámci rozboru nového exempláře pokusíme blíže představit.

\section{NÁLEZ Z HOSTIVICE-PALOUKU゚ Z R. 2011}

Lokalita Hostivice leží jihovýchodně od Prahy a topograficky nemá souvislost s žádným opevněným centrem 10. století. Kostrové pohřebiště můžeme předběžně datovat do 10.-1. poloviny 11. století především na základě nálezů esovitých záušnic malého průměru i exemplářù ze silného drátu (cf. Daněček, Smíšek i Korený 2014, s. 407). Na v rámci Čech spíše větším pohřebišti v Hostivici čítajícím cca 154 hrobů, prozkoumaných v 1. 2008-2013 Středočeským muzeem v Roztokách u Prahy, p. o. , se našly kaptorgy nejméně ve 3 hrobech, ale pouze jedna byla stř́brná a dosti dobře zachovaná. Lépe vybavený hrob H 2103 s kaptorgou ležel v jihovýchodní části pohřebiště a měl nadstandardně dlouhou jámu. Celku se budeme věnovat podrobněji.

\section{Hrob H 2103}

Hrobová jáma byla obdélného tvaru za hlavou spíše oblého tvaru, směrem ke dnu se v spodní části zúžila. K úpravě hrobu snad patřily dva kameny, jeden v nohách. Hrob dospělé ženy (adultus I, 20-30 let) byl uložen v poloze na zádech, paže nataženy podél těla. Orientace kostry Z.-V. Pánev zachována velmi špatně. Náznaky dřevěné konstrukce/truhly byly slabě viditelné, nebyly do plánu zaneseny.

Pozn. Trámčina v dutině horní čelisti je pravděpodobně následkem chronického zánětu (Kubálek 2011). 
Rozměry: $249 \times 99 \mathrm{~cm}$ ve spodní části šiřka jen 66-70 cm, hloubka $44 \mathrm{~cm}$ od úrovně skrývky, pưvodně tedy cca zhruba $84 / 79 \mathrm{~cm}$ od povrchu. Je třeba ještě počitat s erozními procesy, nebot' pohřebiště leži ve svahu. ${ }^{2}$ Objem hrobu se tedy pohyboval mezi 1482-2095 $\mathrm{m}^{3}$. Obr. 1 .

V oblasti hlavy se našly dvě na levé a tři esovitě ukončené záušnice v řadě na pravé straně lebky. U levého konce spodní čelisti ležela stř́brná kaptorga výzdobou navrch $(3$, obr. 1, 2.). Stř́ibrná i fajánsová perla se našly pod lebkou. Chalcedonová? perla se nalezla v dotyku s čelistí (5) pod kaptorgou, další asi též pod lebkou.

1. Dvě stříbrné esovitě ukončené záušnice ze silnějšího drátu, prům. 14 a $15 \mathrm{~mm}$, s. drátu 2,9 mm. obr. 2: 1,2

2. Tři stř́brné esovitě ukončené náušnice ze silnějšího drátu, prům. 13-14, 14-15 mm, síla drátu 2,9 mm. Esovitý konec je roztepán do šíŕky 3,5-4 mm. obr. 2: 3-5.

3. Stříbrná lichoběžníkovitá kaptorga uzavřená víčkem se dvěma otvory pro zavěšení zdobená rytou výzdobou na vybíjeném/puncovaném pozadí na přední straně. Hlavní motiv představuje dvojice afrontovaných ptáků s otočenými hlavami, uprostřed je stylizovaný strom života s mohutným kmenem a dvěma větvemi listovitých úponek; kmen přechází v obrácený srdcovitý útvar, z jehož báze se větve rozbíhají a zároveň je naznačeno obloučkem jejich spojení (uzel). V dolní části kmene se listovité úponky prostě větví. Na nich ptáci stojí. Ptáci mají dlouhé krky, velké zobáky i mohutný ocas, kulaté oko je vyraženo, na krku je zdůrazněno peří. Kř́dla jsou nadzvednutá. Ani zde tak jako v Klecanech není dokonalá symetrie, např. pásek na krku se liší na levé a pravé straně, každé křídlo je provedeno jinak, stejně jako ocas na pravé straně je širší než na levé. Výzdobné pole je motivem prakticky vyplněno a jednou linií orámováno. Víčko je zdobeno zepředu rytým pletencem vytvořeným za pomoci kružítka, shora odlišně provedeným volnějším pletencem, který je proveden méně zručně z více (minimálně 3) proplétaných pásků. Ve dvou případech je vidět přetažení či náznak další krátké linie. Zadní strana je hladká, stejně jako boky. Jedna z částí boku není kompletní. Dobře je patrný detail nastřižení plechu na zadní straně víčka, a spoj na dně kaptorgy. Na pozadí jsou jednoduché mírně protáhlé vpichy, kdežto na hrudi jsou ražené půlobloučky naznačující peří - je tedy užito jiného nástroje. Kaptorga je rekonstruovaná pomocí textilie. Obsah vnitřku i vlákna zjištěná zvenku kaptorgy zveřejňuje tab. 1. Většinu míst odběru ukazuje obr. 2:11. Důležité je, že byl žrejmě podruhé identifikován provázek, na němž byla kaptorga zavěšena, a běžná rostlinná lněná vlákna a zřejmě i kost. Rozměry: $37 / 31 \times 6,2 \mathrm{~mm}$, víčko dlouhé 32,6-33 mm.

Středočeské muzeum Roztoky, Inv. č. 15 139. Obr. 2: 10, 4:1.

Obsah kaptorgy z Hostivice byl zkoumán nejpodrobněji, je zachyceno i rozmístění odebíraných vzorků na a uvnitř předmětu (obr. 2), výsledky předkládáme $\mathrm{v}$ přehledné tabulce 1 .

\footnotetext{
${ }^{2}$ Opakovaně docházelo ke splachům i během otevřené skrývky.
} 


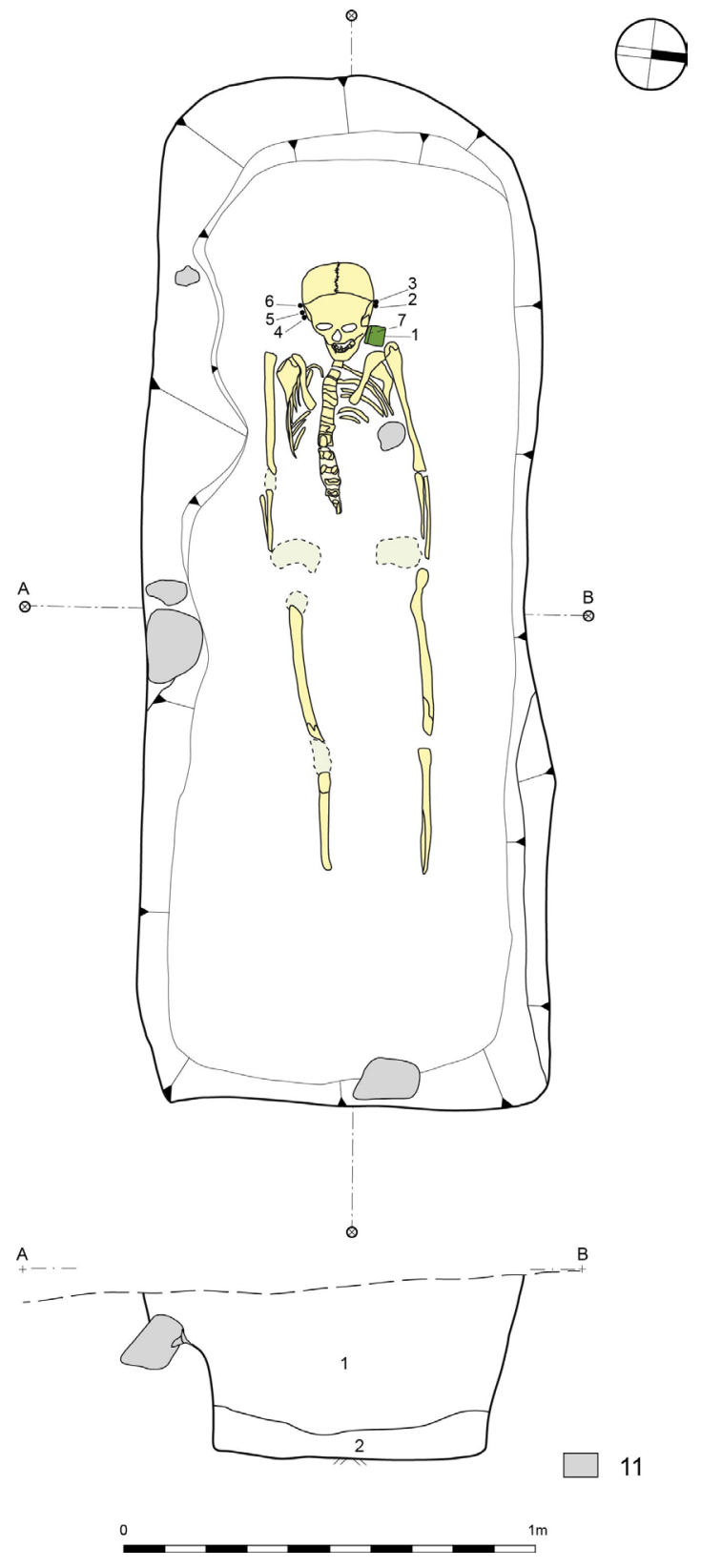

1. Hostivice-Palouky, okr. Praha-západ. Plán hrobu H 2103

1 - hnědočrná písčitá hlína s drobnými kousky opuky, 2 - šedohnědá písčitá hlína. Č. 2, 3, 4, 5, 6 - záušnice, č. 1 kaptorga. Kresba P. Zemanová 

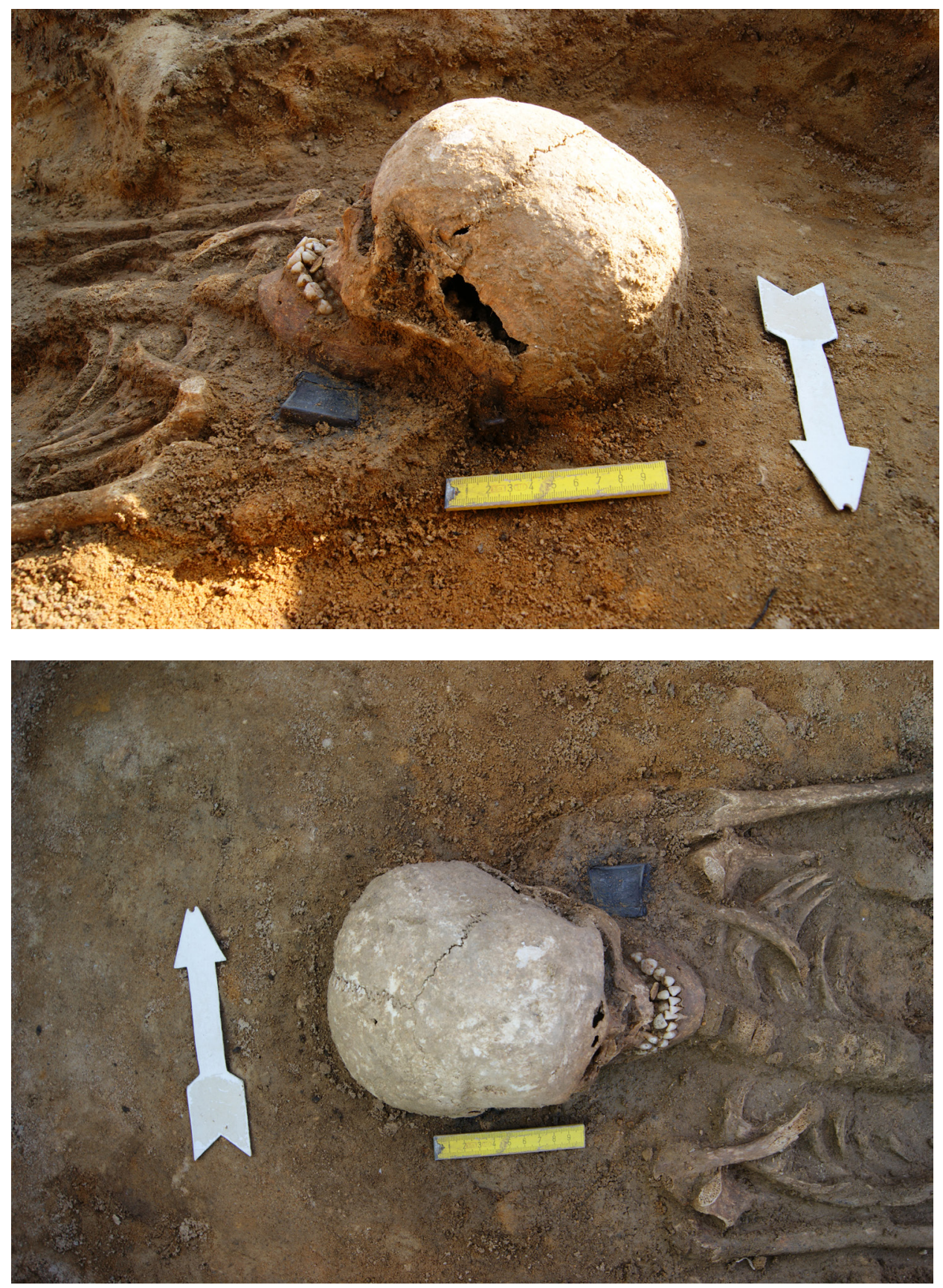

1.2 1.3. Hostivice-Palouky H 2103, detail kaptorgy v terénu. Foto O. Tomek 

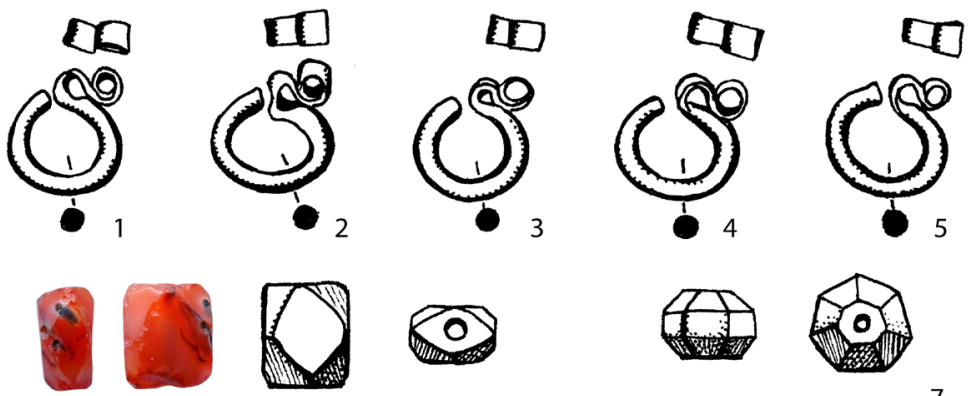

6

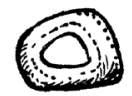

0 $3 \mathrm{~cm}$

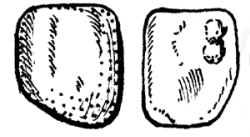

8

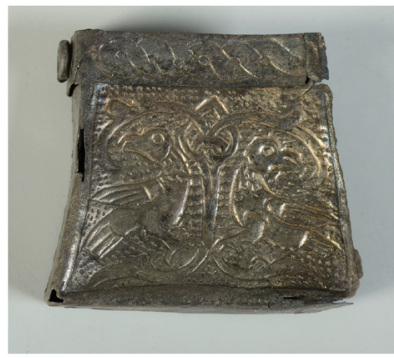

10

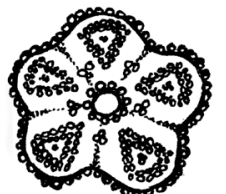

0
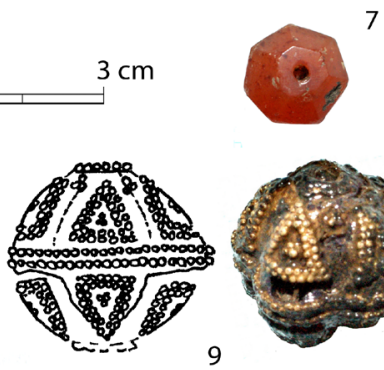

$1 \mathrm{~cm}$

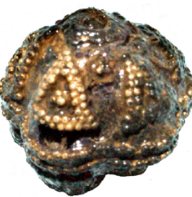

9

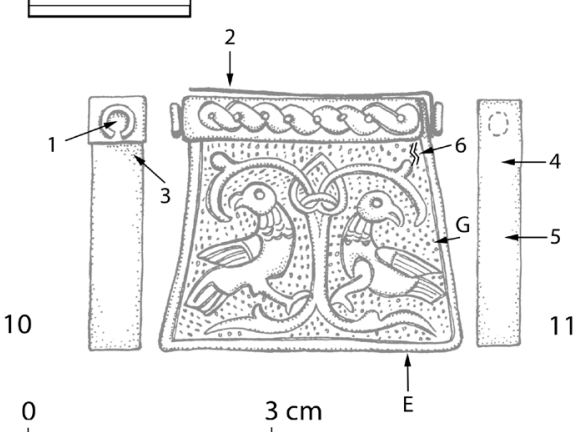

$3 \mathrm{~cm}$

2. Hostivice-Palouky, výbava hrobu H 2103. Kresba L. Raslová. Foto O. Tomek, A. Hůlka (kaptorga)

Náhrdelník se skládal z perly strríbrné, dvou ze sicilského chalcedonu ${ }^{3}$ a jedné skleněné, respektivě z fajánse.

4. Stř́ibrná perla spíše kulovitého tvaru s pětilistým průřezem, ve středu opticky rozdělená pásky granulace a $\mathrm{v}$ každém segmentu zdobená granulovanými trojúhelníky s drobnými granulkami ve středu. Ještě do volného prostoru vkládány útvary tvořené 3 granulkami. D. $10 \mathrm{~mm}$. Obr. 2:9. Uvnitř nedolepené perly skupina kořínků či vláken. Podle infračervené spektroskopie se jedná o lněná a vlněná vlákna VŠCHT Praha (M. Novotná).

${ }^{3}$ Určil V. Šrein pouze makroskopicky, bez odebrání vzorku. Bude provedena ještě Ramanová spektroskopie. 
5. Chalcedonová/karneolová hranolovitá mírně zploštělá perla okosenými rohy se našla pod kaptorgou, na plánku obr. 1: č. 7. D. 14 mm. Obr. 2: 6.

6. Chalcedonová dvoukónická sedmiboká perla s fasetovanou střední ploškou, průměr $13 \mathrm{~mm}$, max. š. $12,3 \mathrm{~mm}$, obr. 2:7.

7. Tyrkysově modrozelená fajánsová perla mírně soudkovitého tvaru o délce $8 \mathrm{~mm} .{ }^{4} \mathrm{Na}$ jedné straně tenčí vrstva polevy, na druhé intenzivnější. Na jednom místě nahloučeny 2 drobné nálitky polevy. Obr. 2. Podle infračervené spektroskopie byl korál barven oxidy mědi (CuO, M. Novotná, VŠCHT Praha).

Tab. 1. Hostivice-Palouky, H 2103. Kaptorga. Přehled vzorků zkoumaných pomocí infračervené spektroskopie uvnitř, ojediněle i vně kaptorgy, měřeno v r. 2012: Laboratoř M. Novotné, VŠCHT Praha, cf. obr. 2, umístění většiny vzorků

\begin{tabular}{|c|c|c|c|}
\hline $\begin{array}{l}\text { Označení } \\
\text { vzorku }\end{array}$ & $\begin{array}{c}\text { Poloha } \\
\text { (viz obr. 2) }\end{array}$ & Určení & Poznámka \\
\hline A & & Včelí vosk + hlinitokřemičitan kaolinického typu (z Čech) & \\
\hline B & & $\begin{array}{l}\text { Celulóza - hmota s obsahem ligninu, } \\
\text { nejde o vlákno, kus dřevěné štěpky- } \\
\text { rozložené degradované dřevo }\end{array}$ & ne kořen \\
\hline $\mathrm{C}$ & & Proteinové vlákno i vlákno celulózy, v sousedství vosk & Interpret: vlna a len, \\
\hline $\mathrm{D}$ & & $\begin{array}{c}\text { Kůže nečiněná či jen máčená do kamence/podvojný síran } \\
\text { hlinitodraselný }\end{array}$ & \\
\hline $\mathrm{E}$ & & Fosforečnan - zbytky kosti?? & \\
\hline E2 & & Kůže činěná pomocí tř́sloviny, např. dubové kůry & \\
\hline $\mathrm{F}$ & & $\begin{array}{l}\text { Klíh (z paznehtů či vyvařené kůže) } \\
\text { Dřevo }\end{array}$ & \\
\hline 1 & Zvnějšku & Celulóza mnb - len mineralizace & Interpret. provaz? \\
\hline 2 & Zvnějšku & Proteinové vlákno - vlna & \\
\hline 3 & & Celulóza/len, vlna + celulóza (tkanina) & \\
\hline 4 & & Kořínek & \\
\hline 5 & & Kořínek - zmineralizovaná celulóza & \\
\hline 6 & & Vlna + celulóza (len) & \\
\hline
\end{tabular}

\section{ANALÝZA KAPTORG TYPU IA SE SYMETRICKÝMI MOTIVY NA PUNCOVANÉM POZADÍ}

Kaptorgy se objevují v hrobech žen a dívek od Baltu na jižní Moravu, jsou známé i na Kyjevské Rusi (jen 2 lokality s depoty), podobně ojedinělé jsou ve lení.

${ }^{4}$ Jádro je ponořeno do skelné frity či roztoku solí, dojde k obalení glazurou a následnému vypá- 


\section{rere?}
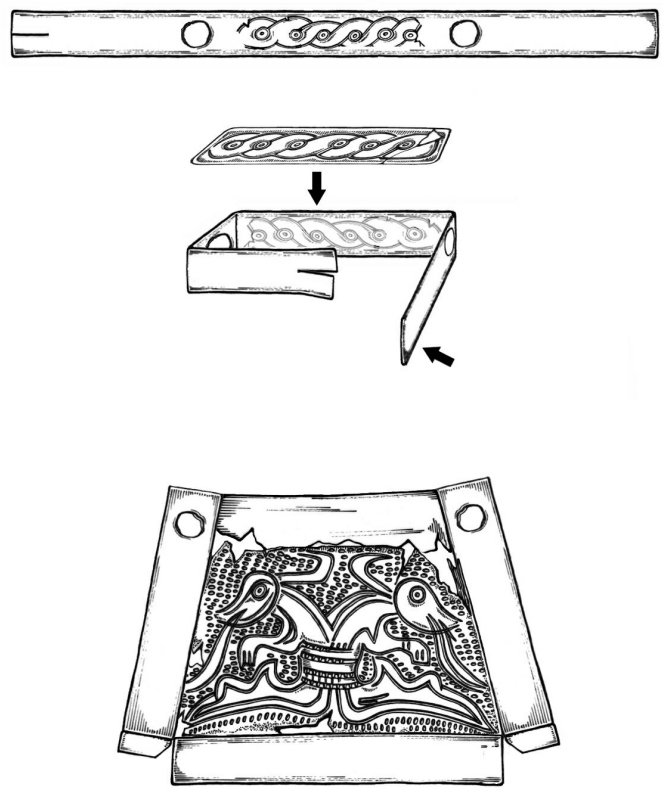

Obr. 6 - Předpokládaný způsob výroby kaptorgy

3.1. Výroba kaptorgy typu IA: rekokunstrukce podle kaptorgy z Klecan II, hrob 22. (Podle Profantová i Šilhová 2010, obr. 8),
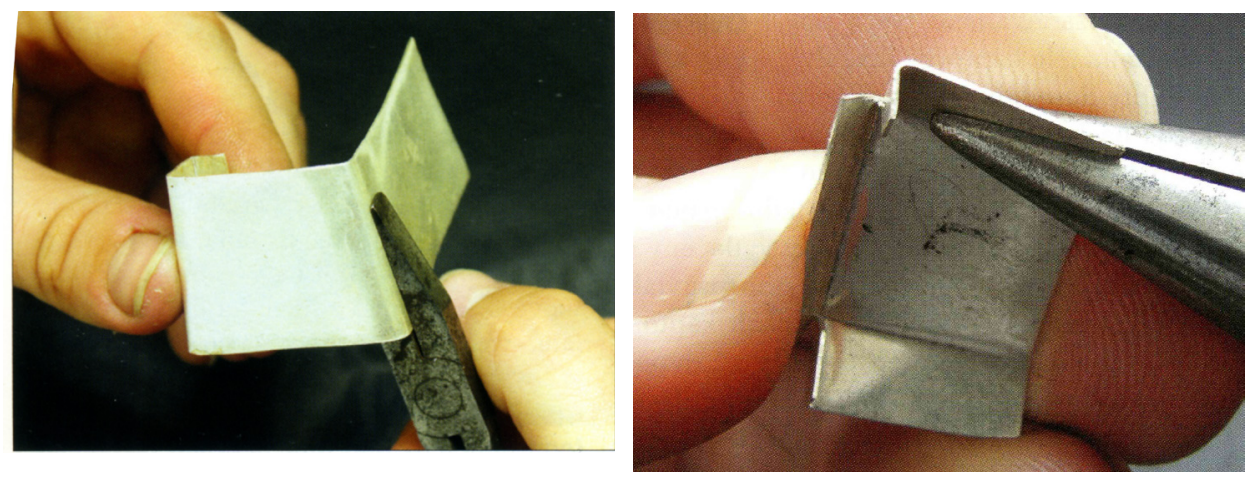

3.2. Ohýbání plechu kaptorgy, 3.3. hýbání bičnic kaptorgy typu IA. 2, 3 podle L. Barčákové 2014. Foto J. Sobek 
Skandinávii (Duczko 1985, s. 232)5. Obecně můžeme říci, že jsou užívány v západoslovanském prostoru, vyjma Slovenska ${ }^{6}$ a území celé karpatské kotliny.

V Čechách jsou kaptorgy známy z 27/28 lokalit, většina nalezišt' se dosud nachází ve středních Čechách, jen na území velké Prahy jde o 6-7 lokalit (zhruba 1/4 $4^{7}$ obr. 8). Několik dalších je známo z Moravy (Staré Město, Olomouc, Břeclav-Pohansko, pohřeb. II, Dolní Věstonice, cf. Štefan 2005, naposl. Macháček, Dresler, Přichystalová i Rybníček 2016, s. 109). Největší koncentrace těchto nálezů pochází z elitního pohřebiště Praha-Lumbeho zahrada, kde se našly ve 5-6 hrobech (6 stř́brných kusů, 1 případ velmi torzovitý, Frolík i Smetánka 2014, Frolík a kol. 2014, obr. 1/35), v jednom z nich byly dva stř́brné kusy.

Kaptorgy se vyráběly ze stříbra, zlaceného bronzu, bronzu, i železa, dokonce se kombinoval ojediněle bronz a železo či železo a organický materiál (Klecany i Profantová 2015, obr. 7:34, 6).

N. Profantová vydělila základních 6 typů kaptorg (Profantová i Šilhová 2010, obr. 13, a Profantová 2015 obr. 7.34, Tab. 12.3), z nichž však jsou tři konstrukční řešení (hlavně IA, IB) mnohem preferovanější než ostatní.

Kaptorgy I B s plastickými animálními hlavičkami v počtu 3-5, zdobené filigránem a granulací - asi nejluxusnější ze všech - známe ze čtyř pohřebišs' ve středních Čechách; tyto jsou nejstaršími zdokumentovanými př́ípady (obr. 8: značka 6B, Profantová 2013, obr. 3 a 5) a vyráběly se v Praze v 1. polovině 10. století. Odsud se šírily do Polska i do severní části dnešního Německa.

\subsection{Základní porovnání}

Vůbec nejběžnější typ kaptorgy v Čechách představuje typ IA (pro Polsko pak typ II podle Styber 2010), tedy lichoběžníkovitá kaptorga vyrobená ze 3-4 základních částí, z nichž dvě vytvářejí víčko a jeden díl je předek s bočnicemi a dnem (obr. 3). Způsob výroby byl odvozen od souboru pod mikroskopem nafocených spojů, které pak byly nacházeny u většiny dalších nálezů tohoto typu, at' již zdobených či nezdobených. Celkem do této skupiny lze zahrnout 19-21 kaptorg (cf. Profantová i Šilhová 2010, tab. 1 a tři nové nálezy včetně Hostivice). Většina $\mathrm{z}$ nich je stříbrná, 8-9 bronzových ( $\mathrm{v}$ jednom př́padě není př́íslušnost $\mathrm{k}$ typu IA zcela jistá). Poměrně silná je vazba stříbrných kaptorg typu IA na hroby dospělých žen ( $8 \times$ oproti 2 bronzovým).

Kaptorgy pak lze ještě třídit podle výzdoby, prrípadně velikosti: na malé (napřr. Zeleneč, Olomouc) a velké (Praha-Lumbeho zahrada: H 16, H 82, Klecany II, H 22 apod.). V rámci typu IA jen pět kaptorg nese animální výzdobu symetricky

\footnotetext{
5 Většinou se jedná o západoslovanské importy.

${ }^{6} \mathrm{Na}$ Slovensku se ojediněle kaptorga asi vyskytla, ale jedná se o zcela jiný typ než nálezy z Čech.

7 Nová z Prahy-Střešovic, Frolíková-Kaliszová 2014, tab. 1.
} 

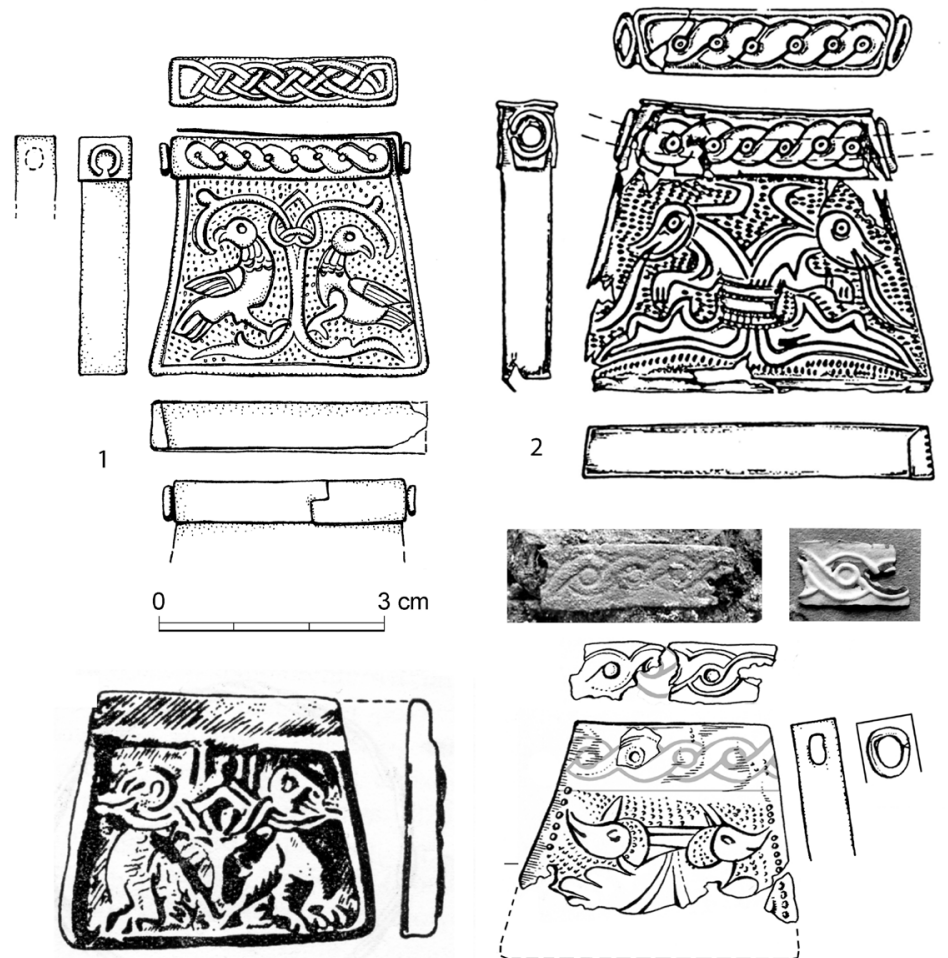

3
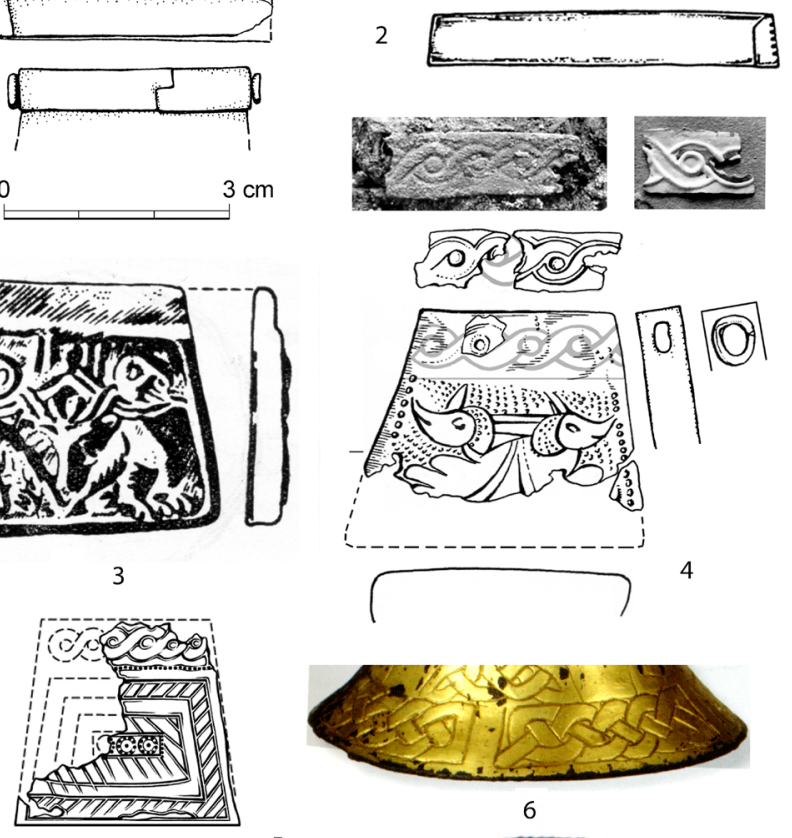

6

5
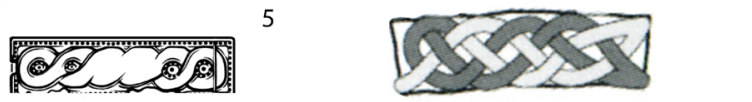

4. Kaptorga z Hostivice a nejbližší nálezy z Čech: 1 - Hostivice, H 2103, 2 - Klecany II, H 22, 3 - matrice Brzesć Kujawski, 4 - Praha-Lumbeho zahrada, H 117 (možná rekonstrukce s víčkem), 5 - pletenec Čelákovice, H 31, 6 - Petöháza, zlacený kalich, detail pletence i zvýraznění jeho struktury. 1-2, 4, 5 Ag, 3 bronz, 6 zlacený bronz. 1 - kresba L. Raslová, 2 - Podle Profantové a kol. 2010, tab. 94, 3 - Podle Kostrzewski 1962, obr. 225, 4 - Podle Frolík i Smetánka 2014, doplněno, 5 - Podle Profantová, Špaček i Novotná 2011, 6 - podle B.M. Szöke 2014, s. 23 
uspořádanou podél svislé osy, čtyři jsou z hrobů (viz níže) a jedna z depotu z Žatce, uloženého do země okolo roku 1015 (Obr. 8, Profantová i Šilhová 2010, obr. 11:3).

My se zaměříme na malou skupinku v rámci tohoto typu, kaptorgy spíše větších rozměrů, které spojuje uplatnění ryté animální výzdoby a puncovaného pozadí a užití pletence na víčku případně bocích (tab. 3, obr. 8: značka 1). Nezařadili jsme tam kaptorgu z depotu z Žatce, je provedená neuměle, nemá dochováno víčko, může být i mladší.

Do této úzké skupiny jsme zařadili jen 4-5 lokalit ze středních Čech, přitom Hostivice $^{8}$, Klecany a Praha-Lumbeho zahrada, H 117 vznikly ve stejném dílenském okruhu (obr. 3-4), který jen hypoteticky lokalizujeme do Prahy. Hostivice představují nejdokonalejší provedení z této trojice. Kaptorga z Čelákovic (Profantová, Špaček i Novotná 2011) může být jen volně inspirovaná předchozími kusy, zviŕre je pojato neuměle, je ozdobeno či děleno svislým páskem ve středu, geometricky je zdobená i rubová strana. To je dost výjimečné. U poslední kaptorgy z Kovár-Budče nelze jednoznačně říci, zda jde o motiv ptáků či symetrický rostlinný motiv. Ten je totiž v Čechách též doložený a asi u nálezu z Budče pravděpodobnější (Váňa 1995, obr. 97, Profantová i Šilhová 2010, obr. 21).

V př́ípadě Klecan jsou bájná zvířata interpretována nejspíše jako kozli (rohy, kopýtka) př́padně kozorozi, hlavu a přední tlapy mají provedeny precisně, zbytek těla schematicky9. V Praze-Lumbeho zahradě jsou hlavy zvířat tvarovány obdobně (obr. 4: 2, 4), ovšem mají jakýsi útvar spíše připomínající výrazné ucho či chochol než roh, tlamy mají zavřené, spodní část výjevu se nedochovala, je pravděpodobné, že záměr mohl být vytvořit okřídlená zvířata (náznak křídla, ozdobu hlavy mají ptáci vyobrazení na gombících). Hlavy jsou spojené jakýmisi pásky - to prripomíná upoutání ptáků na kaptorze z Brześcia Kujawskiego (obr. 4: 3). Motiv je této z trojice provedený nejschematičtěji, na fotografii není dobře vidět dělící linie těla hůře dochovaného zvíŕete, na kresbě je zachycena. V prŕípadě Klecan, jsou na detailech vidět opravy linií rytce (retušované přetahy linie v oblasti rohu, ale i pletence), detailní linie bez správné symetrie (3 a 2 linie na hřbetě zvířat), oko je přeraženo (obr. 5: 1, 3). Puncování pozadí tvoří mírně protáhlé body. Rub kaptorgy v Klecanech nese rýhování (místy ve dvou vrstvách, obr. 5: 2), to je na jednom zlomku patrné i v prrípadě Prahy-Lumbeho zahrady. Pletenec byl v posledním př́ípadě lokalizován jako boční strana (Frolík i Smetánka 2014, s. 194) - obě bočnice však podle kresby ohnutí i studia z autopsie hlavní díl kaptorgy měl. Podle našeho názoru šlo o víčko, které je doloženo kromě pásku s pletencem ještě zlomkem s otvorem obtočeným drátkem (obr. 4:4, správně již Ottenwelter - Děd Barčáková 2014, 263). Boky kaptorgy jsou hladké s poměrně neuměle

\footnotetext{
${ }^{8}$ Hostivice - Praha-Lumbeho zahrada vzdušnou čarou 9,5 km, Praha-hrad - Klecany cca $12 \mathrm{~km}$.

9 To je známo jak z byzantského umění - sarkofág Theodoty z Pavie ( 8 stol.), tak ze severského prostředí cf. Profantová i Šilhová 2010, obr. 11:7 a 5)
} 

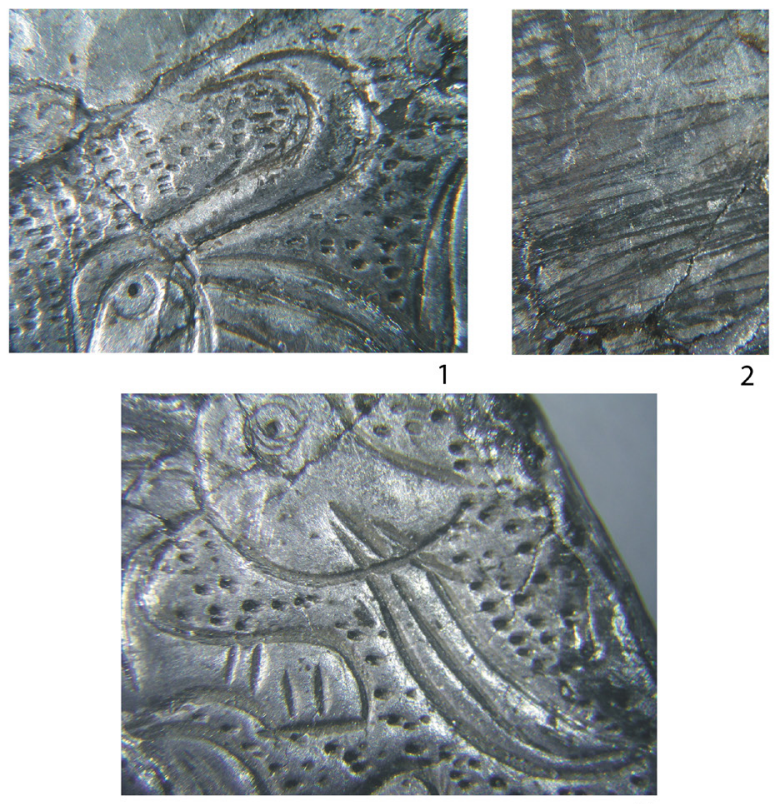

3
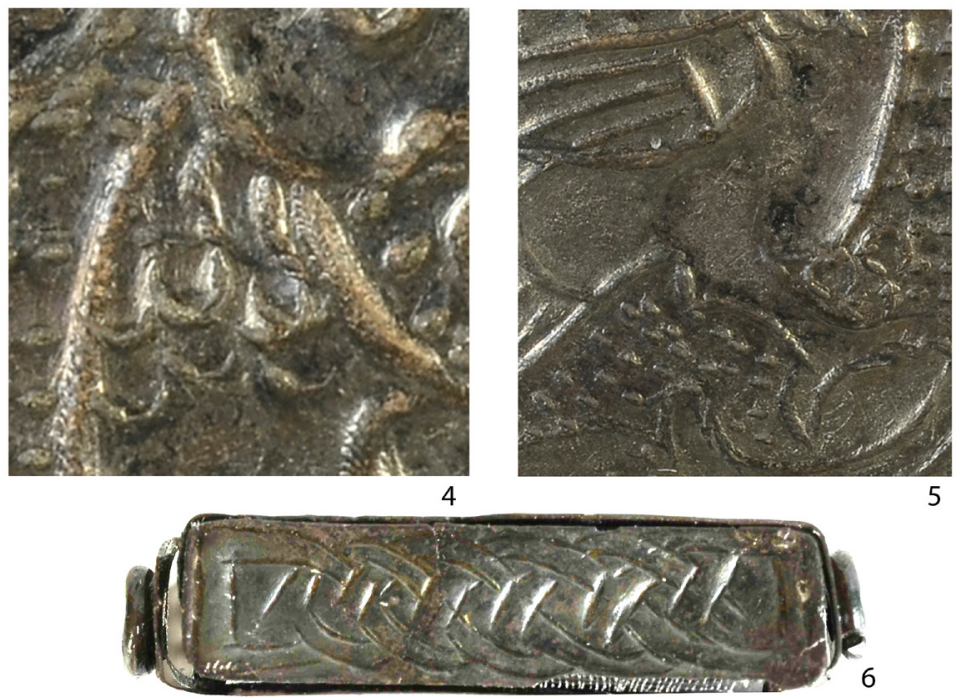

5. Klecany II, H 22: detaily provedení výzdoby kaptorgy dokládají použití různých nástrojů: 1 postup při vytváření oblé linie (přetahování), 3 opakované záměrné vyražení oka $\mathrm{s}$ jistým posunem, 2 ryté linie z vnitřní strany kaptorgy, 4, 5, 6 Hostivice, 4,5 , naznačení peří na hlavě, detail pařátu, 6 detail víčka shora. 1-3 Podle Profantová i Šilhová 2010, obr. 14, zbytek.

Foto A. Hůlka 
provedenými otvory, ten na levé straně je nejspíše protáhlý díky nošení - druhotně $(2 \times 3 \mathrm{~mm}$, obr. 4:4). I v př́ípadě původně rozlámané kaptorgy z Klecan jsme nejprve považovali pás s pletencem za bok, teprve důsledným lepením všech drobných částí se prokázalo, že jde o víčko ${ }^{10}$. Šíŕka 7-7,6 mm odpovídá víčku širokému $10 \mathrm{~mm}$ v Klecanech, kde je kaptorga o něco větší (tab. 3). Velikostí byla kaptorga z Prahy nejmenší (tab. 3, obr. 4: 4). Na druhou stranu v Čelákovicích se kaptorga rekonstruovala tak, že pletenec byl y na dně kaptorgy a chyběl pak jeden bok i víčko, nelze vyloučit, že jde o vzácné řešení1 ${ }^{11}$, ale vzhledem ke stavu kaptorgy $\mathrm{v}$ terénu se na to nelze zcela spolehnout (obr. 4: 5 jen rub).

Porovnání všech dochovaných pletenců ukazuje také obr. 4. Zatímco u kaptorgy z Klecan zjišt'ujeme jen malý rozdíl mezi pletencem na přední straně a na horní straně víčka (obr. 4: 2), v prípadě Hostivice můžeme doložit dva odlišné typy pletence užité na víčku (obr. 4: 1, 5: 6). Ten užitý zepředu je blízký horní straně víčka z Klecan, ale směřuje opačným směrem. Ten užitý shora víčka ve středoevropském prostředí zdomácněl nejspíše koncem 8. a začátkem 9. století, poměrně blízký je pletenec užitý na zlaceném kalichu z Petöházy v Mad’arsku obr. 4: 6 (Szöke 2014, fig. s. 23) vyrobeném asi +Cundpaldem (nápis) mezi lety $770-830$ v bavorském klášteře (širší Salzbursko). Poté se dostal na břeh Ikvy u Süttöru (Szöke 2014, s. 24) a souvisí nejspíše s r. 803, kdy se avarský tudun stal vazalem Karla Velikého či dobou těsně následující. Motiv je odvozený z kontinentálního stylu raně karolinského umění, objevuje se i v knižní malbě. Je zřetelné, že určité tradice se ve špičkových dílnách udržely, i když všechny výrobky doložitelné $\mathrm{v}$ celém čase nemáme.

Honosnější kaptorgy mají pletence tvořené filigránem (Kolín, Praha-Lumbeho zahrada - i více pásy pletenců, Frolík a kol. 2014, obr. 1/35), nejspíše jisté napodobení a zlevnění výroby vedlo k výzdobě rytým pletencem. Obdobné ryté pletence provedené kružítkem známe i z parohové industrie konce 9.-10.století, především hřebenů a plochých obkladů ve středních Čechách (např. Levý Hradec, Budeč, Libice apod. Kaván 1958, tab. V: 2, tab. VII: 6 Libice), právě nález z Libice má blízko přední straně kaptorgy z Klecan, Levý Hradec naopak k horní.

\subsection{Analýzy kovu}

Všechny tři nálezy z této skupiny kaptorg byly analyzovány z hlediska kvality stříbra pomocí RFA, případně SEM, jedná se o předměty z Klecan II, Prahy-Lum-

\footnotetext{
${ }^{10}$ Evidentně nebyly u kaptorgy z Prahy-Lumbeho zahrady vyzvednuty všechny zlomky, chybí minimálně 1 kolečko lemující otvory víčka, dno a část zadní strany. V terénu nejspíše šlo zachytit ještě kompletní výšku kaptorgy, nedošlo však k tomu. Rekonstruovaná výška je odvozena od proporcí shodných s klecanským kusem, byt’ absolutně menší.

11 Pletenec z filigránu měly ze spodní strany i kaptorgy z Prahy-Lumbeho zahrady, H 16 a 82 cf. Frolík a kol. 2014, obr. 1/35: 1, 2.
} 
beho zahrady, H 117 a Hostivice. Klecanský nález představuje téměř čisté stř́bro 96, 6 a 97,8\%, slitinu doplňovala podle rentgenfluorescenční analýzy měd' $(\mathrm{Cu}$ $1,4 \%)$ a zlato $(0,4 \%)$, podle destrukční chemické analýzy bylo mědi mezi $3-4 \%$ uvnitř plechu (J. Děd, VŠCHT Praha). Stř́ibro bylo zasažené mezikrystalickou korozí (Profantová i Šilhová 2010, s. 303, obr. 9: 1, 3). Produkty koroze pak odpovídaly prostředí se zvýšeným obsahem organických látek.

Složení kaptorgy z Prahy-Lumbeho zahrady je obdobné, kolísá od 93,6 (kroužek víčka) do 98,5\% Ag (povrch kaptorgy - líc), povrch víčka obsahoval 94,4\% Ag, zbytek měd' (analýza SEM, Ottenwelter, Děd i Barčáková 2014, s. 263). Víčko je silné $0,1 \mathrm{~mm}$. V ostatních špercích $\mathrm{z}$ tohoto pohřebiště se prríměs mědi pohybovala okolo 2,1\%. Hostivická kaptorga byla pomocí RFA také zkoumána ve Středočeském muzeu v Roztokách, výsledky předkládáme na tabulce 2. Je až pozoruhodně shodná $\mathrm{s}$ oběma nálezy ${ }^{12}, \mathrm{~s}$ tím $\mathrm{z}$ Klecan ji pojí i zjištěná př́měs zlata. Je velmi pravděpodobné, že stříbro zpracovávané v jedné dílně mělo i stejný zdroj. Nejvyšší zastoupení ryzího Ag bylo zjištěno na kroužcích na vičku, to ukazuje připravený drát, $\mathrm{z}$ nějž se odstřihávaly drátky $\mathrm{k}$ výrobě kroužků.

Tab. 2. Materiálové složení kaptorgy z Hostivice-Palouků. Měřila P. Witoszková

\begin{tabular}{|c|c|c|c|}
\hline $\begin{array}{c}\text { Hostivice Palouky 2011 } \\
\text { KAPTORGA č. 15 139 }\end{array}$ & $\mathrm{Cu}$ & $\mathrm{Ag}$ & $\mathrm{Au}$ \\
\hline přední rytá část & 5,61 & 93,87 & 0,52 \\
\hline zadní část bez výzdoby & 5,01 & 94,49 & 0,5 \\
\hline vrchní část víka & 4,66 & 94,78 & 0,57 \\
\hline kroužek & 3,81 & 95,52 & 0,66 \\
\hline
\end{tabular}

\subsection{Motiv ptáků u stromu života}

Motiv ptáků u stromu života je velice rozšířený v prostoru (pozdně římské, byzantské i raně islámské prostředí) i v čase. Než přistoupíme k rozboru výjevu, zdůrazníme masivnost ptáků mn - nejedná se rozhodně o pávy ani holuby, velký zoban, mohutný spuštěný ocas a pařáty připomínají spíše sokola (obr. 5:5), jak je znám z velkomoravského výjevu (cf. Galuška 2000, s. 204, č. 08.02.11) nebo dravce z gombíků z Břeclavi-Pohanska (Kalousek 1971, obr. 38 a, tab. 32: 1, 2). Podle posouzení ornitologa L. Peške, se nejspíše jedná o orla (krátká kř́ídla vzhledem

\footnotetext{
12 Ovšem každou kaptorgu měřil vždy někdo jiný na jiném přístroji (Klecany mnb - Řež u Prahy, Praha - VUT Brno).
} 


\begin{tabular}{|c|c|c|c|c|c|c|}
\hline 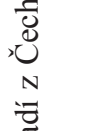 & 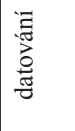 & 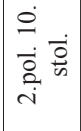 & 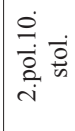 & $\begin{array}{l}\dot{0} \\
\dot{0} \\
\dot{0} \overrightarrow{0} \\
\dot{d} \\
\dot{0}\end{array}$ & $\begin{array}{l}\dot{0} \\
\dot{0} \\
\dot{0} \\
\dot{0}\end{array}$ & 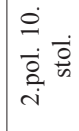 \\
\hline 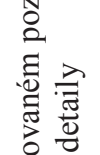 & 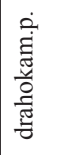 & $x$ & $x$ & $x$ & $\cong$ & $x$ \\
\hline 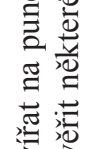 & 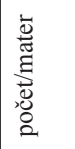 & $\begin{array}{l}\frac{00}{4} \\
3 \\
0 \\
\frac{0}{0} \\
\frac{8}{2}\end{array}$ & $\sum_{i n}^{\infty}$ & 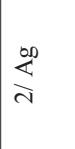 & $\nsubseteq$ & $\frac{\infty}{4}$ \\
\hline 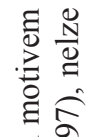 & 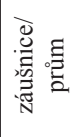 & $\begin{array}{l}0 \\
\pm \\
\pi \\
n \\
n\end{array}$ & 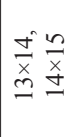 & $\begin{array}{l}\text { d̃ } \\
x \\
\text { à } \\
\text { a }\end{array}$ & $\cong$ & $\begin{array}{l}\vec{d} \\
\vec{x} \\
\end{array}$ \\
\hline 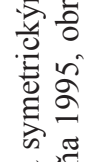 & 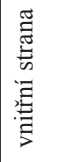 & 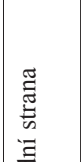 & & 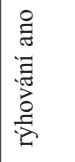 & a. & 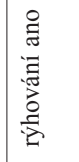 \\
\hline$\frac{0}{2} \stackrel{0}{\circ}$ & 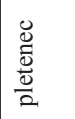 & $\frac{3}{8}$ & 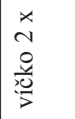 & 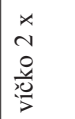 & $\cong$ & 曾 \\
\hline 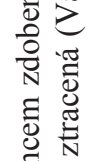 & 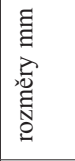 & 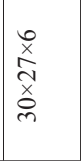 & 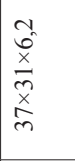 & $\begin{array}{l}n \\
0 \\
0 \\
x \\
0 \\
\tilde{x} \\
x \\
0 \\
y\end{array}$ & $\begin{array}{l}n \\
\tilde{a} \\
d \\
x \\
\\
\end{array}$ & 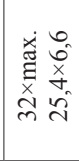 \\
\hline 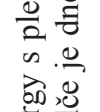 & 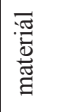 & 象 & ${ }_{4}^{\infty}$ & ${ }^{\infty}$ & $\ddot{n}$ & 㤎 \\
\hline 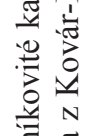 & 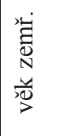 & $\begin{array}{l}\frac{\pi}{50} \\
\frac{50}{02} \\
08 \\
0\end{array}$ & $\begin{array}{l}0 \\
\text { ஸे } \\
\text { ஸे }\end{array}$ & 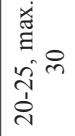 & 0 & $\begin{array}{l}0 \\
0 \\
1 \\
o\end{array}$ \\
\hline 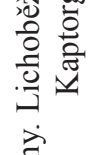 & 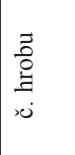 & $\vec{m}$ & 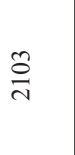 & $\tilde{N}$ & 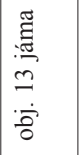 & $\cong$ \\
\hline $\begin{array}{l}\dot{0} \\
\dot{0} \\
\dot{\sigma}\end{array}$ & 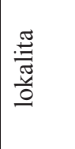 & 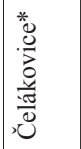 & 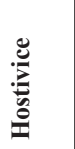 & 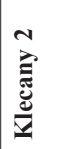 & 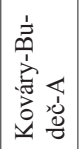 & 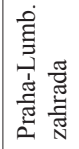 \\
\hline
\end{tabular}


k dlouhému ocasu i tvar těla), „zvlnění“ (ražené půlobloučky) na krku může naznačovat jiné ,zbarveni““ oproti jednolitému břichu. ${ }^{13}$

Chocholka naposledy zmíněného ptáka pak připomíná útvar na hlavách z kaptorgy v Praze-Lumbeho zahrady, H 117 (obr. 4: 4). Tato pozorování ukazují mimo jiné domácí zpracování přejaté kompozice a oslabení jasné křest'anské interpretace. Masivnost ptáků charakterizuje i polské kaptorgy s tímto motivem (obr. 4: 3).

Výzdoba kaptorgy z Hostivice je provedená nejkvalitněji, výrobce znal nejspíše bud' jiné zpracování takového motivu (iluminaci, hedvábnou látku, jiný drobný předmět) nebo jiné kaptorgy s takovým motivem. Kaptorgu s podobným motivem známe především z Maszenic (Inowrocław), depotu uloženého až v 1. polovině 11. století (Śląski i Tabaczyński 1959, tab. XII: 2 dole), může tedy jít o nález o něco mladší, vyrobený v 1 . třetině 11 . století. Chybí puncované pozadí, ptáci jsou se stromem propojeni, zobrazení je stylizovanější snad i plastičtější. Strom života má relativně podobnou stylizaci a vyplňuje většinu výzdobného pole. Více detailů se z nekvalitního vyobrazení nedá vyčíst, není jasné, jaké se uchovaly technologické detaily (přehnutý spojený plech na dně apod.). Považovala se za výrobek orientálního původu (Stattler 1966, s. 236).

Pro motiv dvou afrontovaných ptáků dotýkajících se ocasy upoutaných ke stromu života známe totiž bronzovou matrici k výrobě kaptorg z Brześcia Kujawskiego (obr. 4: 3, Kil-Byczko 1970, obr. 1; Kostrzewski 1962, obr. 225). V tomto případě se objevuje výklad, že nemusí jít o ptáky, ale bájná zvířata s tělem částečně ptačím, částečně psím, což by odkazovalo na mytologického Simurga, kde jsou oba zvíŕecí elementy obsaženy již v názvu (Gasowska 1979, s. 138). Oproti našemu výjevu však „ptáci“ stojí obráceně (ocasy směrem ke stromu) a hlavu nemají otočenou. „Psí prvky“ na vyobrazení nelze rozlišit. Existuje matrice, ale paradoxně zatím chybí kaptorga podle ní vyrobená.

Tento motiv se vyskytuje $\mathrm{v}$ byzantském prostředí či uměleckém řemesle tímto okruhem ovlivněném od 6 . století poměrně často, na náušnicích, nákončích a kováních opasku (Komar i Strelnik 2009, ris. 4) a též na toreutice (ovšem tam dochované spíše mladší nádoby (napřr. Darkevič 1975, obr. 67 ze 12. století). Z 10. století uvádím alespoň výjev dvou afrontovaných ptáků u stylizovaného stromu života pocházející z Egypta a zachycený v mramoru (Seipel 1999, s. 83, č. 13.). Důležité je i šíření motivu pomocí hedvábných látek. V této souvislosti je tř̌eba zmínit část béžového hedvábí utkaného jako protolampas z hrobu sv. Ludmily $(+921)$ v kostele sv. Jiř́ v Praze, podrobným rozborem je látka datovaná do 1. třetiny 11. století (obr. 6: 3). Látka byla původně částí dalmatiky (biskupského oděvu) ${ }^{14}$ a dostala se do Čech nejspíše přes Německo (shoda s hedvábím z Hildesheimu: Bravermanová 2001, s. 450 n, obr. 12, Bravermanová 2006, s. 205). Jedná se o hedvábí byzantské či syrské, př́ípadně z oblasti Mezopotámie, ptáci však

\footnotetext{
13 Orli mají na krku takové „zvlnění“ a jinak jsou jednobarevní. L. Peške tímto velmi děkuji.
}

14 Dalmatiku dostal i sv. Vojtěch od císaře Oty, Bravermanová 2001. 


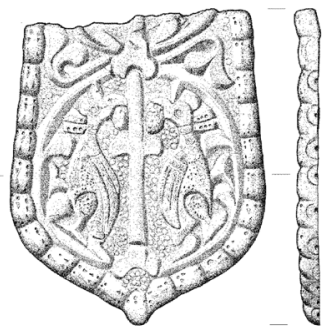

1

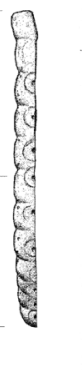

2

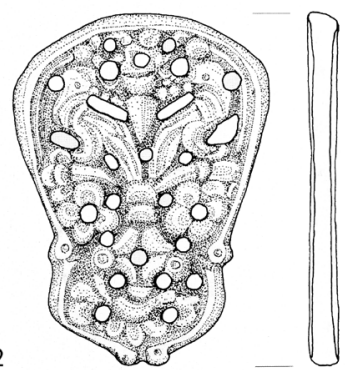

$3 \mathrm{~cm}$

0

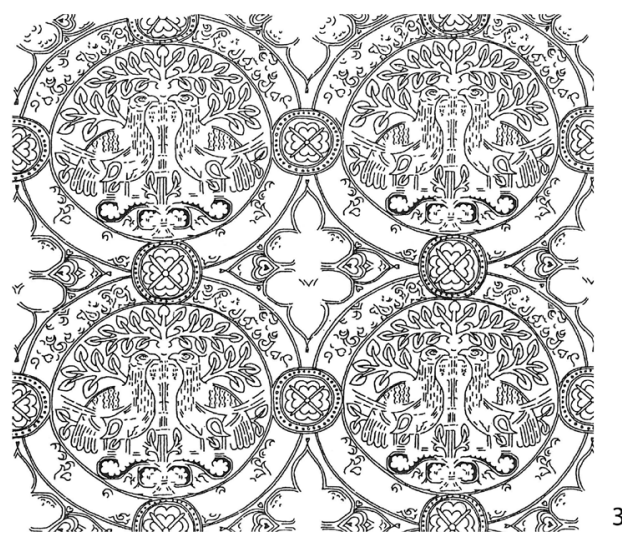

6. 1 - Mikulčice nákončí, CZ, 2 - St. Kanzianberg, A, 3 - Praha, CZ hedvábí z hrobu sv. Ludmily. 1, 2 - podle Daim 2000, Abb. 46b, 50b, 3 - podle Bravermanová 2001, obr. 12

nemají otočené hlavy a strom je pojat realističtěji. Pro vazbu na středoevropský prostor je důležité zlacené kování zdobící koňský postroj ve 3. čtvrtině 8. století, z Kanzianbergu u Mallestigu (Rakousko). V prolamované technice je tam výjev dvou ptáků s otočenou hlavou u silně stylizovaného stromu života, ptáci stojí ,na větvích stromu“ spojeného uzlíkem a v spodní části opět rozvětvené (obr. 6: 2, Daim 2000, s. 127-128, Abb. 50b). Spolu s níže zmíněným nákončím z Mikulčic ukazují dvě základní varianty motivu, s ptáky s otočenou a neotočenou hlavou oba známé v širší středoevropské oblasti, St. Kanziansberg ukazuje na lokální recepci mediteránních impulsů. V České republice zachycujeme tento motiv v 8 . století na importovaném zlaceném stříbrném nákončí z Mikulčic (obr. 6: 1, Profantová 2010, Abb. 28: 9), ovšem z 9. století není doložen. Kaptorga z Hostivice ukazuje, že se tu nejspíše pod cizím snad jihovýchodním vlivem objevil znovu v 10. století. Stylizace ptáků mohla navázat na některé gombíky s tímto motivem z 2. poloviny 9. a první třetiny 10. století (např. Frolík a kol. 2014, obr. 1/34: 12, stylizace je však bližší nálezům z Moravy, např. už zmíněné Břeclav-Pohansko či 
Mikulčice-Těšické, Kouřil 2014, s. 407, obr. 283). Podobná stylizace se však vyskytla i na toreutice, konkrétně stříbrné míse orientálního původu, nalezené jako východní import ve Švédsku a datované do 10. století (detail: Klanica 1970, obr. 16).

Stylizovaný strom je poměrně jednoduchý, a těžko jednoznačně svým provedením lokalizovatelný. Motiv afrontovaných ptáků u nedochovaného stromu života se objevil též na obdélném dosud nepublikovaném kování, importovaném do středních Čech ze západu.

Motiv je v obecné rovině spojován oprávněně s křest’anskou symbolikou a šíríl se spolu s šířením křest’anství. V případě střední Evropy je však třeba jeho vazbu na křest'anství zkoumat vždy individuálně. Motiv užitý v Hostivici zobrazuje jednoznačně dravé ptáky, to zdůrazňuje výběžek na noze ptáka vyobrazeného z hlediska výjevu vpravo.

V př́ípadě kaptorgy z Hostivice není rozhodně jednoznačné, že byla křest'anská symbolika nositelkou takto chápána, Hostivice představují pohřebiště bez kostela, které není jako celek elitní. Objevují se na něm nádoby jako obaly na potravinové milodary, tedy spíše zvyky odvozované z pohanského názoru na posmrtný život. Tomu odpovídá též magický obsah kaptorgy. Je pravděpodobné, že se jednalo o případ určité synkreze motivu a praktického užívání kaptorgy. Pokud se majitelka setkala s vysvětlením křest’anského významu vyobrazení, necítila jej rozhodně jako protikladný k ochranné úloze obsahu kaptorgy, spíše asi jako posilující tento význam.

Celkově lze říci, že po výjevu lovu s pomocí sokola ze Želének (9. stol., např. Profantová 2014, obr. 1) představuje takto zpracovaný motiv jeden z nejkvalitnějších výjevů, jaké se v Čechách dochovaly. Zároveň se jedná o jeden z dalších dokladů vysoké úrovně domácí šperkařské produkce 10. století.

\section{DATOVÁNÍ HROBU Z HOSTIVICE}

Pohřbená byla vybavena kolekcí stř́brných šperků (obr. 1, 2), které ve své kombinaci odkazují na 2. polovinu 10. století, maximálně na přelom 10. a 11. století (Profantová 2013; Krumhanzlová 1974). Granulovaná stř́ibrná perla patří k poměrně častěji se vyskytujícím v hrobech - oproti některým je však stlačenější - kulovitější. Kombinace dvou až tř́ stříbrných perel s polodrahokamovými se vyskytla napřr. v Klecanech II, hrobě 23 - vůbec nejbohatěji vybaveném v rámci malé nekropole (Profantová 2011, Fig. 9; Profantová a kol. 2010, tab. 95, fototab. 93; Profantová 2015, tab. 12.4 a obr. 12.16). V tomto prŕpadě je hrob 23 z Klecan o málo starší než hrob 22 z Klecan II s kaptorgou, je řazen do středu 10. století. Perla však sama nemůže zpřesnit datování hrobu ${ }^{15}$, spíše jen ukazuje na větší do-

${ }^{15}$ Není jasné, jaké typy perel přecházejí do závěru 10. století a počátku 11. stol., nelze vyloučit že většina typů. 

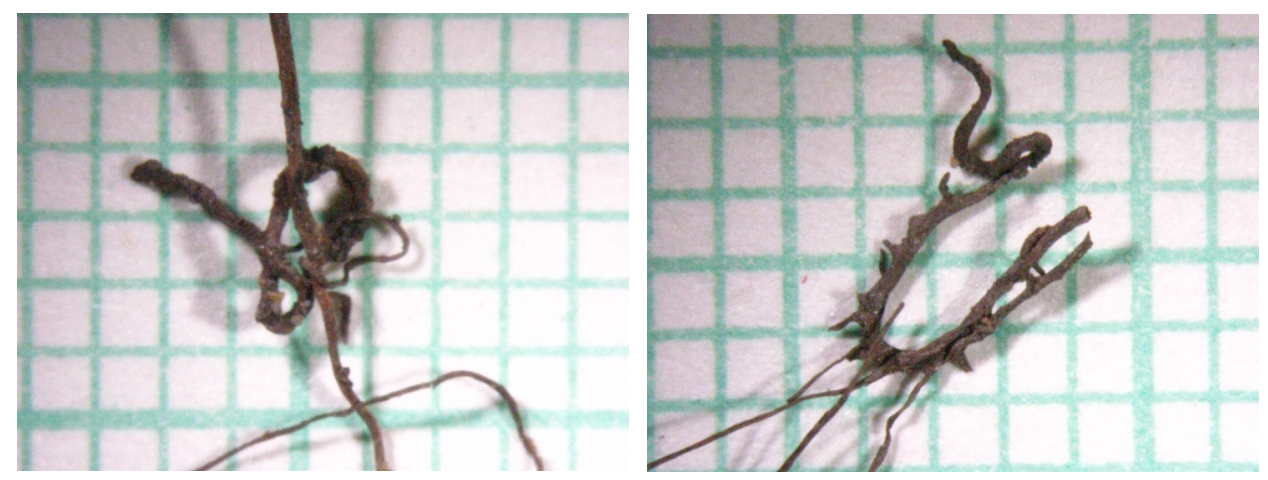

7. Hostivice-Palouky, H 2103. Kaptorga a detaily z obsahu kaptorgy. Vzorky 1, B, C. Foto M. Novotná

stupnost těchto výrobků mimo hlavní centra. Jednotlivá stříbrná perla se_vyskytla jen s 1 vlasovým kroužkem i na elitním pohřebišti v Praze-Lumbeho zahradě (hrob 25, Frolík i Smetánka 2014, 75). Jiná jednotlivá stř́brná perla jen s filigránovou výzdobou byla v hrobě 17 v Klecanech II s náušnicemi s očky z téže doby. Obecně díky pětilistému řezu patř́ českému typu III, může jít i o samostatnou variantu. Kulovitější tvar ji pak přibližuje typu IV, známého dosud jen z rekonstrukce poškozené perly z Klecan II.

Výskyt polodrahokamových perel je v Čechách doložen od 1. poloviny 10. století, ve druhé polovině jich mírně přibývá a objevují se početnější kolekce (Profantová 2015, s. 172, tab. 12.4.). Fajánsový tyrkysový korálek je v raně středověkých Čechách výjimečný, snad pomůže studiu kontaktů (jih a jihovýchod?), chalcedon byl nejspíše též dovezen z jihu, případně východu. Ve středních Čechách se objevil v Klecanech II, Praze-Lumbeho zahradě i na spíš venkovských lokalitách jako je Praha-Motol (Kováŕík 1991, tam spíše konkrétně karneol). Fajánsový korálek je výjimečný - jediný v Čechách, mohl se $\mathrm{k}$ nám dostat ze Středomoří a to i zprostředkovaně, ale z chronologického hlediska není využitelný.

Výbava hrobu z Hostivice odpovídá časově jak hrobu z Prahy-Lumbeho zahrady nověji posunutého do 2. poloviny či poslední třetiny 10. století (Frolík a kol. 2014, obr. 1/49 $)^{16}$, tak výbavě z Klecan II, tam se odkryly podobné záušnice ze silnějšího drátu s obdobným průměrem (Tab. 3, Profantová i Šilhová 2010, obr. 3). K oběma zmíněným hrobům nemáme absolutní data, hrob z Klecan II leží v severozápadní části nekropole, tj. v části, která tvoří dvě řady s koncentrací významných pohřbů mladší fáze pohřbívání.

\footnotetext{
16 Rozpaky budí jen křišt’álové dvoukónické perly - které se jako první v Čechách objevily na tomto pohřebišti, avšak v hrobě 99 se vyskytla taková perla s gombíky, celek nelze datovat později než 50.-60. leta 10. století. Hrob se jeví jako začátek nejmladší fáze pohřbívání.
} 


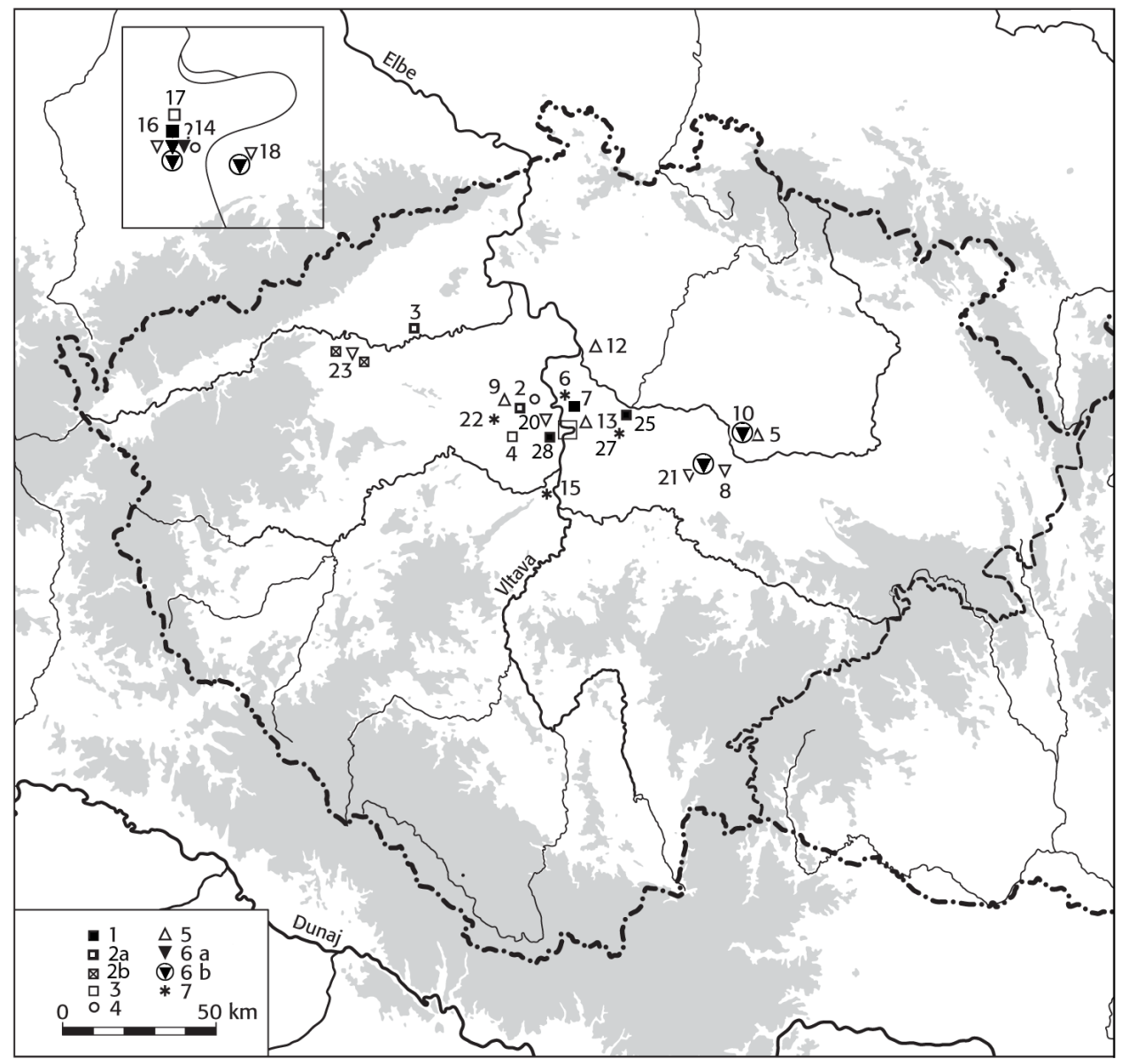

8. Mapa kaptorg v Čechách, výzdobné motivy

1 - Plný čtverec: Symetrická rytá výzdoba zviŕă na puncovaném pozadí zároveň s motivem rytého pletence (dílna Praha), $2 \mathrm{a}$ - animální motivy v plochém reliéfu, $2 \mathrm{~b}$ - animální motiv symetrický na puncovaném pozadí, bez pletence, 3 - animální motiv na puncovaném pozadí (Ag, bez symetrie), 4 - symetrická rytá rostlinná výzdoba na puncovaném pozadí, 5 - nezdobené kusy, 6a zdobené granulací a filigránem, $6 \mathrm{~b}$ animální plastický motiv s granulací a filigránem(koníčci), 7 - jiná výzdoba. Č. 7 nejisté, zda animální či rostlinná výzdoba.

Významné a zmiňované lokality: 4 - Dobrovíz, 6, 7 - Klecany I a II, 9 - Kováry-Budeč, 10 - Libice nad Cidlinou, 16 - Praha-Lumbeho zahrada, 18 - Praha-Václavské nám., 21 - Koư̌im, 23 - Žatec, 25 - Čelákovice, 28 - Hostivice. Podle Profantová i Šilhová 2010, obr. 12 doplněno

V nově odkrytém hrobě v Klecanech (H 1/017), pohřebiště I jsou též 4 stříbrné záušnice ze silnějšího drátu, a datum ${ }^{14} \mathrm{C}$ se pohybuje $\mathrm{v}$ intervalu celého 10 . století, ale kalibrovaná 1 sigma varianta data jen v intervalu 966-993 AD při 78\% pravděpodobnosti (Světlík 2017). To odpovídá poznatkům o skupině hrobů se sledovanými kaptorgami. 


\section{ZÁVĚR}

Kaptorga z Hostivice pochází z hrobu datovatelného do 2. poloviny 10. století až přelomu 10./11. století, jeho výbava časově odpovídá jak hrobu 117 z Prahy-Lumbeho zahrady, tak výbavě z hrobu 22 z Klecan II, kde jsou též záušnice ze silnějšího drátu (tab. 2). Přestože se kaptorga vyskytla na pohřebišti bez prŕmé souvislosti s hradištěm a spíše venkovského rázu, provedení motivu je nejkvalitnější z blízké trojice nálezů. Výroba kaptorgy zdobené rytím ovšem nebyla časově příliš náročná ve srovnání s granulovanými kusy, u klecanské kaptorgy byla stanovena na 17 hodin (poznatek L. Barčákové). U kaptorgy z Hostivice předpokládáme obdobnou časovou náročnost. Minimálně výše zmíněné tři kaptorgy vznikly ve stejné dílně v Praze, mohla $\mathrm{k}$ nim patřit i nedochovaná kaptorga $\mathrm{z}$ Budče.

Obsah kaptorgy z Klecan II i Hostivice je srovnatelný (rostlinná vlákna, kost, snad dřevo, obr. 7), navíc se zjistily stopy klihu, vosku a činěné kůže. Kůže i se záhybem se objevila v kaptorze v Čelákovicích (Profantová, Špaček i Novotná 2011); proteinová vlákna: chlupy či vlasy jsme zjistili v kaptorze z Klecan I, hrobu $1 / \mathrm{F}$, tam byl také zjištěn též vosk. Zcela nově byl určen tedy klíh - ten zřejmě souvisel s lepením kovových přehybů, tedy s procesem výroby.

Ve všech blíže srovnávaných hrobech představovaly pohřbené ženy sociálně významnější osoby, dokládá to mimo vlastní schránky výskyt polodrahokamových perel, asi i masivnost stř́brných záušnic, v prŕípadě Hostivice i jejich počet, stejně jako výskyt speciálních chirurgických nožů s celokovovou cínovanou rukojetí v př́ipadě hrobu z Klecan II. Pouze žena z Prahy-Lumbeho zahrady měla opravdu bohatý náhrdelník složený z desítek skleněných perel a 4 perel drahokamových (křištál, karneol) a tří jantarových, mohlo jít o náhrdelníky dva (delší a krátký). Její statut - už pro výjimečnost pohřebiště - byl asi nejvyšší ze sledovaných žen ${ }^{17}$. $\mathrm{Na}$ druhou stranu $\mathrm{v}$ rámci konkrétní komunity mohla mít žena $\mathrm{z}$ Hostivice stejně privilegovanou pozici jako žena z Prahy v rámci své celkově privilegovanější skupiny.

Kaptorga z Hostivice přináší jeden z nejkvalitnějších ucelených výjevů, jaké se v Čechách dochovaly a vyráběly (kaptorga z Dobřichovic je patrně import). Motiv sám má širší vazby na jihovýchodní oblast, je možno jej označit za recepci mediteránních předloh zprostředkovaných snad textiliemi (obr. 6:3) či jinými výrobky; v 11. století se ptáci u stromu života objevili na importovaném koltu kyjevského typu z Roudnicka či Mělnicka (Polabí a střední Čechy; Militký 2000 s fotografií). Motiv mohl být dále předáván do polského prostředí (Maszenice), ovšem mohl se tam dostat i jinou cestou. Je zřejmé, že řemeslník měl nějaký vzorník motivů, které nabízel a př́padně individuálně upravoval.

${ }^{17}$ I v Polsku se stříbrné kaptorgy objevují především v bohatě vybavených hrobech - cf. Sztyber 
V Polsku chybí uplatnění klasického středočeského rytého osmičkovitého pletence, ovšem v Maszenicích se nedochovalo víčko kaptorgy.

Zároveň výrobek představuje jeden $\mathrm{z}$ dalších dokladů vysoké úrovně domácí české šperkařské produkce 10 . století. V rámci lokální komunity se radil hrob H 2103 z Hostivice k nejbohatěji vybaveným.

\section{LITERATURA}

Barčáková L. 2014, Výroba raně středovékého šperku naleziště v Lumbeho zahradě na Pražském hradè, w: J. Frolík a kol., Pohřebišt ě v Lumbeho zahradě na Pražském hradě II. Studie, Castrum Pragense 12,1. Praha, Archeologický ústav Praha,v.v.i., s. 311-430.

Bravermanová M. 2001, Nové poznatky o nejstaršich textiliích z relikviářového hrobu sv. Ludmily, Archaeologia Historica, 26, s. 447-486.

- 2006, Textil nejstaršich Přemyslovců, w: P. Sommer (ed.), České země v raném středověku, Praha, Lidové Noviny, s. 193-212.

Daim F. 2000, Byzantinische Gürtelgarnituren des 8. Jahrhunderts, w: F. Daim (ed.), Die Awaren am Rand der byzantinischen Welt, Wien, s. 77-204.

Daněček D., Smíšek, K., Korený, R. 2014, Předběžná zpráva o terénním výzkumu pohřebiště z mlaď̌i doby stěhování národů v polykulturni lokalité Hostivice-Palouky, okr. Praha-západ, w: B. Komoróczy (ed.), Archeologie barbarů 2011, Sociální diferenciace barbarských komunit ve světle nových hrobových, sídlištních a sběrových nálezů, Spisy Archeologického ústavu AV ČR Brno, 44, s. 407-418.

Darkevič V.P. 1975, Prikladnoje isskustvo v Vizantii v VI-XII vv. Proizvedenije vizantijskogo chudožestvennogo remesla v Vostočnoj Evrope X-XIII veka, Moskva.

Duzcko W. 1985, Birka V. The Filigree and Granulation work of the Viking Period, Uppsala.

Frolík J. a kol. 2014, Pohřebišt ě v Lumbeho zahradě na Pražském hradě II. Studie. Castrum Pragense 12,1. Praha, Archeologický ústav Praha, v.v.i .

Frolík J., Smetánka Z. (ed.), Pohřebiště v Lumbeho zahradě na Pražském hradě, Castrum Pragense, 12,1, Praha 2014.

Frolíková-Kaliszová D. 2014, Pohřebiště z 10. století v Praze-Střešovicích-předběžná zpráva, Archaeologia historica, 39, s. 315-329.

Galuška L. 2000, Zierscheibe mit Reiter (Falkner) - Motiv, w: A. Wieczorek, H.M. Hinz (ed.), Europas Mitte um 1000, Katalog, Stuttgart, 204.

Gąsowska E. 1979, Bizancjum a ziemie pótnoczno-zachodniostowianskie we wczesnym średniowieczu. Studium archeologiczne, Wrocław-Warszawa-Kraków-Gdańsk.

Kalousek F. 1971, Břeclav - Pohansko I. Velkomoravské pohřebiště u kostela - Gräberfeld bei der Kirche, Spisy Filozofické fakulty Masarykovy univerzity, 169. Brno.

Kavan J. 1958, O zpracováni a výzdobě kosti u západních Slovanů, Vznik a počátky Slovanů II, s. 253-285.

Kil-Byczko E. 1970, W sprawie pochodzenia i funkci kaptorg trapezowatych, I. medzinaradowy kongres archeologii słowianskiej, t. 5, Warszawa, s. 423-427.

Klanica Z. 1970, Velkomoravský gombik - Der großmährische „Gombik“", Kugelknopf, Archeologizké rozhledy XXII, s. 421-446.

Koćka-Krenz H. 1993, Biżuteria pótnocno-zachodnio-stowiańska we wczesnym średniowieczu, Poznań.

Komar A.V., Strelnik M.A. 2009, Podražanije zolotomu vizantijskomu pojasnomu naboru VII. V. s izobraženiem ptic, Rossijskaja archeologia, 2, s. 148-159.

Kostrzewski J. 1962, Kultura prapolska, Warszawa.

Kouřil P. 2014 (ed.), Velká Morava a počátky křestanství. Brno. Archeologický ústav AV ČR Brno, v.v.i.

Kováŕík J. 1991, Slovanské kostrové pohřebiště v Praze 5 - Motole - Das slawische Skeletgräberfeld in Prag $5 m n b$ - Motol, Praha, Muzeum hl. Města Prahy.

Krumphanzlová Z. 1974, Chronologie pohřebniho inventáre vesnických hřbitovů 9.-11. věku v Čechách - Die Chronologie des Inventars aus Dorffriedhöfen des 9.-11. Jh. in Böhmen, Památky archeologické, 65, s. 34-110. 
Kubálek P. 2011, Základní antropologické zpracování lidských kosterních nálezů z výzkumu v Hostivici, okr. Praha-západ, provedeném v roce 2011 během akce Tulipan Park, Č́st 2. Nepublikovaná zpráva.

Kucypera P. Wadyla S. (ed.), Życie codzienne przez pryzmat rzeczy, Toruń, 43-62.

Macháček J., Dresler P., Přichystalová R., Rybníček V. 2016, Břeclav-Pohansko VII. Kostelni pohřebiště na Severovýchodním předhradí, Spisy Filozofické fakulty Masarykovy univerzity 455, Brno.

Militký J. 2000, Schmuckhort, w: A. Wieczorek, H.M. Hinz (ed.), Europas Mitte um 1000, Katalog, Stuttgart, s. 114-115.

Ottenwelter E., Děd J., Barčáková L. 2014, Technical study of jewellery from the „Lumbe Garden “ cemetery at Prague castle, w: J. Frolík a kol. (ed.) Pohřebišt ě v Lumbeho zahradě na Pražském hradě II. Studie, Castrum Pragense 12,1. Praha, Archeologický ústav Praha, v.v.i., s. 163-310.

Profantová N. 2010, Awarische Funde in der Tschechischen Republik Forschungsstand und neue Erkenntnisse, Acta Archaeologica Carpathica, 45, Kraków, s. 203-270.

- 2011, New Evidence concerning Dating, Importance and Hinterland of Early Medieval Hillfort of Klecany, district of Prague-East, w: J. Macháček, Š. Ungerman (ed.), Frühgeschichtliche Zentralorte in Mitteleuropa, Studien zur Archäologie Europas 14, Bonn, 355-370.

- 2013, Ke změnám ve vývoji hmotné kultury 10. století v Čechách, Archaeologica Historica, 38, 27-44.

- 2014, Mocenské elity v Čechách 9.-10. století, w: P. Kouřil, Velká Morava a počátky křest'anství, Brno, 56-63.

- 2015, Klecany. Raně středověká pohřebiště I. Praha. Archeologický ústav AV ČR Praha, v.v.i. a nakladatelství Epocha.

Profantová N. a kol. 2010, Klecany. Raně středověká pohřebiště II. Praha. Archeologický ústav AV ČR Praha.

Profantová N., Šilhová A. 2010, K problematice kaptorg v Čechách. Na základě detailního studia hrobu 22 z Klecan II - Frühmittelalterliche Kaptorgen in Böhmen. Analyse eines Fundes aus Grab Nr. 22 auf dem Gräberfeld Klecany II, Památky archeologické CI, Praha, 283-310.

Profantová N., Špaček J., Novotná M. 2011, Nové poznatky o výrobě a obsahu kaptorg, na základě studia hrobů ze Zelenče a Čelákovic, okr. Praha-východ, Archeologie ve středních Čechách 15, s. 539-552, Fototab. 14.

Seipel W. 1999, Schätze der Kalifen, Islamische Kunst zur Fattimidenzeit, Kunsthistorisches Museum Wien.

Stattler E. 1966, Kontakty handlowe ludności wczesnopolskiej z krajami arabskimi we wczesnym średniowieczu (IX-XI), „Slavia Antiqua“, 13, s. 199-269.

Světlík I. 2017, Klecany, pohřebiště I, H 1/17. Nepublikovaná zpráva, Praha.

Szöke B.M. 2014, The Carolingian Age in the Carpathian Basin. Budapest.

Sztyber A. 2006, Wczesnośredniowieczne kaptorgi z terenu ziem Polski, Kraków. Praca magisterska, Uniwersytet Jagielloński, Instytut Archeologii.

- 2010, Funkcja i znaczenie kaptorg we wczesnym średniowieczu.

Śląski J., Tabaczyński S. 1959, Wczesnośriednowieczne skarby srebrne Wielkopolski, Warszawa-Wrocław.

Štefan I. 2005, Kaptorgy: pokus o kontextuální analýzu, Studia Mediaevalia Pragensia, 5, Praha, s. 21-60.

Váňa Z. 1990, Svět slovanských bohů a démoni̊, Praha.

- 1995, Přemyslovská Budeč. Archeologický výzkum hradiště v letech 1972-1986 - Zusammenfassung, Praha, Archeologický ústav AV ČR.

Vida T. 1995, Frühmittelalterliche scheiben und kugelförmige Amulettkapseln zwischen Kaukasus, Kastilien und Picardie, Bericht RGK, 76, s. 219-291. 